local residents, usually members of Rural Community Councils, in the welfare of village craftsmen; and the employment by Rural Community Councils of a Rural Industries Organizer. Details of the work of the Rural Community Councils and of the Rural Industries Bureaux are included in the report.

Although the Commissioners are not directly concerned with the provision of work for the unemployed, assistance has been given to two admirable schemes relating to land cultivation-the Allotment Scheme of the Society of Friends and Central Allotments Committee and the Land Settlement Association. Stress is laid upon the experimental character of these schemes for converting the unemployed industrial worker into an independent landholder and on the need for organization in this field if our natural resources are to be used to full advantage. Assistance has also been given to the Agricultural Camps Committee.

While the agricultural section of the report is concerned only with administrative matters, the section on fisheries includes an account of work reviewed by the Commissioners' advisory committee on fishery research as well as progress reports submitted by the directors of institutions receiving grants in aid of fishery investigations. The difficult situation at Armstrong College, Newcastle-upon-Tyne and the Dove Marine Laboratory, Cullercoats, since the financial emergency of 1931 , due to the fact that the staff were partly engaged in 'directed' research on the local herring fishery and on pollution in the Tyne for the Ministry of Agriculture and Fisheries, for which the Minister's vote was drastically reduced, has been met by initiating a new grant period of five years in the form of a single block grant towards the total maintenance expenses of the Laboratory. Tribute is paid to Prof. Hobson's determination and ability in overcoming the difficulties and re-organizing research and to the value of the Laboratory in supplementing the fishery researches of the Ministry. Continued support of Prof. A. C. Hardy's investigations at University College, Hull, on the influence of plankton on fisheries is recommended ; and reference is made to the development at Conway through investigations on shellfish of a cleansing process for mussels which eliminates the danger of carrying typhoid, and this process has been adapted to the purification of oysters. Other investigations in this field are concerned with the reliability of bacteriological methods for the routine testing of shellfish for sale, and grants have also been given for the development of freshwater fisheries, including in. vestigations of salmon and sea-trout.

Grants for fishery research are made from the Development Fund either to the Fishery Department for 'directed' researches on problems immediately affecting the economic development and exploitation of fisheries, or to universities, colleges and marine laboratories for 'free' research, with the object of increasing our knowledge of the animal and plant life of the sea in relation to its whole environment. In the first category fall the important investigations on the difficult problems connected with herring fisheries, which differ for England and for Scotland. In Scottish waters the Fishery Board's investigations have shown that the shoaling of the herring on the drift-net grounds in early summer is associated with the search by groups of fish from different sources and of different types for the rich food-plankton then present in northern waters. In the great autumn fishery off Yarmouth and Lowestoft, however, the fish are on a migration preliminary to spawning and the shoals are not feeding. The investigations of the English Fishery Department have led to the issue of much more accurate forecasts of this autumn fishery. Other directed investigations have been concerned with inshore fisheries such as the popula. tion of small plaice in sand bays on the east coast of Scotland with a view to determining how far the stock needs protection by regulation of fishing. Diseases of freshwater fish, such as furunculosis, have also been studied, while among the 'free' researches assisted may be mentioned Dr. H. B. Moore's investigations on animal and plant life of the seashore, the cause of the dying out of eel-grass or grass. wrack and on artificial hatching and stocking of salmon fisheries.

Enough has been said, however, to indicate the wide range and importance of the Development Commissioners' contribution to scientific research. Equally it would seem that the Development Fund contains possibilities of co-ordinating the national effort in research, which might well be applied in very much wider fields.

\title{
The Chemist in Industry
}

HE Society of Chemical Industry concerns itself
very largely with the practical application of
chemistry, and in the main operates through its
subsidiary groups, of which there are four, and its
numerous sections in Great Britain, in the Dominions
and in the United States. Once a year, at the annual
general meeting, the Society as a whole meets at the
headquarters of one of the sections and like the
British Association it visits the Dominions and the
United States from time to time. This year the
annual meeting will be held at Harrogate, though
Leeds is the headquarters of the Yorkshire Section,
and next year the meeting will be in Canada. At
these meetings the business of the Society is dealt
with, addresses are delivered, a few papers are read, works and places of interest are visited, but the social atmosphere predominates.

About a year ago, however, the Council came to the conclusion that some matters of general interest to chemists and the chemical industry as a whole could only be dealt with at conferences specially convened, and accordingly it appointed a strong committee with Dr. Wm. Cullen as convenor to give effect to its decisions. The Manchester Section was anxious that the first conference should be held there, and no more appropriate place could have been chosen.

As the subject chosen for the symposium held on April 2, namely, "The Chemist in Industry", was somewhat wide, and indeed vague, it was decided 
that there should be two sessions, one in the afternoon and the other in the evening, at which sub-divisions of the general subject should be discussed. The subject of the afternoon session was the "Induction and Functions of the Chemist", and that of the evening session, "His Influence and Reward".

Eight short papers were prepared and all were published in advance of the meeting in Chemistry and Industry. In addition, reprints were available at the meeting. Two rapporteurs were appointed to summarize the papers, namely, Dr. R. H. Pickard, director of the Shirley Institute, for the afternoon session, and Mr. C. J. T. Cronshaw, managing director of the British Dyestuffs Corporation, for the evening session. In the unavoidable absence of Lord Leverhulme, president of the Society, Mr. W. A. S. Calder, a past president, presided over the conference.

By adopting this arrangement, practically the whole of the time available was devoted to the discussions, and it may be said that the speeches on the whole were excellent. The immediate point under discussion was seldom lost sight of, and so far as the first session is concerned, it looks as if the Committee would be in a position to come to definite conclusions which it is hoped will be helpful to the universities and colleges on one hand and industry on the other. As might have been expected, the discussions centring around the subject for the evening session were less helpful, but inspiring nevertheless.

No attempt will be made to summarize these discussions here. In due course they will no doubt be published, together with the conclusions of the Committee, but it is quite clear that the symposium has justified itself, and others will no doubt follow in due course.

The following is a list of the writers of the papers, all of whom were requested to confine themselves, so far as possible, to their own experiences: Afternoon Session: Dr. J. J. Fox (Government Chemist) ; Prof. J. C. Philip (Imperial College of Science and
Technology); Mr. F. Scholefield (College of Tech. nology, Manchester); Mr. C. M. Whittaker (Courtaulds, Ltd.). Evening Session: Mr. H. Ballantyne (Lever Bros., Ltd.); Mr. G. E. Collins (Shirley Institute) ; Dr. A. E. Dunstan (Anglo-Iranian Oil Co., Ltd.); Mr. J. Rogers (Imperial Chemical Industries, Ltd.).

It will be observed that the writers of these papers covered a very wide field, from both the academic and industrial points of view, and though the whole field could not be covered, this defect was remedied largely by the discussion in which twenty-five persons, all men of standing, took part.

It is just as impossible to summarize the papers as the discussion, but one or two points have emerged :

(a) For certain classes of work, graduate chemists do not appear to be sufficiently trained in manipulative technique, possibly through the attempt to put too much into the curriculum.

(b) There has been too little contact between industry and the teaching institutions generally.

(c) There is a large demand for chemists whose training from the start is along definitely technical, as opposed to purely academic, lines.

(d) For success in other walks of life, such as administration, business, salesmanship, and even finance, chemical training forms just as good a background as any other.

Probably the most striking statement made during the symposium was by Mr. C. M. Whittaker, who said: "In my experience there are just as many fools walking about with high academic qualifications as there are able men walking about with lesser academic qualifications, but of greater ability and deserving of greater financial reward."

In this connexion the views of many of the speakers, which seemed to be endorsed by the very large audiences present, were that the avenues to inclusion in the profession should not be closed in the slightest degree to those who had the desire to better themselves.

\section{Forestry in the Gold Coast}

$\mathrm{T}$ HE annual report of the Forestry Department of the Gold Coast for the year 1935-36 (Accra : Govt. Printing Dept., 1936) by Mr. R. C. Marshall, conservator of forests, is written in non-technical language and gives evidence of progress in the introduction of a sound forest administration.

Cocoa forms one of the staple exports of the Colony, and the protection of a certain area of forests in the right situations is indispensable to this industry. It has been established by the research work carried out under the Cocoa Research Scheme at the Imperial College of Tropical Agriculture in Trinidad that an even moisture status is one of the characteristics of a good cocoa soil, and environmental studies have demonstrated that the moisture status of both soil and atmosphere have important bearings on crop productivity. The chief function of shade trees in cocoa cultivation is to provide a buffer against fluctuations in environmental conditions. This lesson was learnt many years ago in Madras and Ceylon in connexion with coffee and the tea gardens and other forms of planting cultivations.
The clearing of large blocks of forest and the hacking which took place in those remaining in the neighbourhood led to serious erosion, desiccation of the soil and so forth; this led to heavy losses and considerable areas going out of cultivation. If the conditions in the Gold Coast are to be adequately preserved, where such preservation is not altogether too late, "the requirements of this industry need to be considered from time to time by the Forest Agricultural Departments in collaboration with the Administration".

Mr. Marshall considers three types of protection forest reserves as required in the Colony : $(a)$ head. water reserves, $(b)$ barrier reserves, and $(c)$ shelterbelt reserves. It is said that reservation has been so far concentrated on $(a)$ the protection of headwaters and (b) the barrier reserves situated between the edge of the closed forest zone where it marches with the drier open (savannah) forest; the idea being to stay the encroachment of dry conditions. During the year, the chief attention has been paid to what are termed (c) the shelterbelt reserves. These latter are to be 